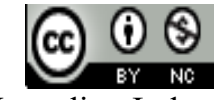

Jurnal Bimbingan Konseling Indonesia is licensed under A Creative Commons Attribution-Non Commercial 4.0 International License.

\title{
PENGEMBANGAN APLIKASI EVALUASI PROSES LAYANAN DASAR (APPRODA) BERBASIS WEBSITE
}

\author{
Firmansyah $^{1)}$, RA Murti Kusuma ${ }^{2)}$, Aip Badrudjaman ${ }^{3)}$ \\ ${ }^{1)}$ Magister Bimbingan dan Konseling, Fakultas Ilmu Pendidikan, Universitas Negeri Jakarta, Indonesia \\ E-mail: firmansyah_848813@yahoo.co.id \\ 2) Program Studi Teknologi Pendidikan, Fakultas Ilmu Pendidikan, Universitas Negeri Jakarta, Indonesia \\ E-mail:murti@unj.ac.id \\ ${ }^{3)}$ Program Studi Bimbingan dan Konseling, Fakultas Ilmu Pendidikan, Universitas Negeri Jakarta, Indonesia \\ E-mail:aip.bj@unj.ac.id
}

\begin{abstract}
Abstrak: Upaya meningkatkan profesialisme guru, konselor perlu melaksanakan evaluasi untuk memperoleh penyelenggaraan layanan dasar sesuai dengan harapan siswa serta berkualitas. Pelaksanaan evaluasi program bimbingan dan konseling melalui kegiatan layanan dasar dijadikan konselor sebagai pengembangan program bimbingan dan konseling di sekolah. Namun dalam upaya tersebut, pelaksanaan evaluasi belum dilaksanakan dengan baik dengan angka kesuksesannya sebesar 18,75\% dan hanya 49,62\% yang melaksanakan evaluasi proses. Melihat dari kecilnya angka kesuksesan dan pelaksanaan evaluasi proses, maka perlu diketahui masalah yang dihadapi oleh guru dalam pelaksanaan evaluasi proses layanan dasar. Berdasarkan observasi dan studi kebutuhan yang melibatkan guru BK SMA Negeri 43 Jakarta sebanyak 14 guru diketahui bahwa guru BK belum sepenuhnya melakukan karena keterbatasan waktu, rasio guru BK dengan siswa yang tidak ideal serta kekurang pahaman dalam mengevaluasi proses layanan dasar bimbingan dan konseling. Dengan ditemukannya permasalahan tersebut, perancangan sebuah alat bantu dalam pelaksanaan evaluasi proses layanan dasar dapat membantu menyelesaikan masalah yang dihadapi oleh guru BK. Perancangan alat bantu dalam pelaksanaan evaluasi proses layanan dasar menggunakan aplikasi berbasis website dengan jaringan aktif (online) bernama Aplikasi Evaluasi Proses Layanan Dasar (APPRODA). Berdasarkan hasil validasi ahli media dan materi, APPRODA masuk dalam kategori sangat layak dan layak dengan didapat nilai presentase sebesar 92,94\% dan 71,42\% sehingga APPRODA telah memiliki kesesuaian dengan materi dan media yang baik dan dapat diuji coba pada pengguna. Dalam uji coba, APPRODA melibatkan tenaga pendidik (guru BK) dengan hasil presentase sebesar 97,25\% sehingga APPRODA dikategorikan sangat membantu dalam evaluasi proses layanan dasar.
\end{abstract}

Kata Kunci: Perancangan; Evaluasi Proses Layanan Dasar BK; Website

\section{Pendahuluan}

Bimbingan dan konseling bertujuan untuk membantu para siswa mencapai tugas-tugas perkembangannya, memfasilitasi dan memandirikan peserta didik dalam rangka tercapainya perkembangan yang utuh dan optimal, mencapai aktualisasi diri dan memahami dirinya sendiri, memberikan dampak positif dalam kehidupan siswa, mampu menyelesaikan masalah-masalahnya saat ini dan siap menghadapi kehidupan yang akan datang [1]. Hal-hal tersebut dapat tercapai salah satunya melalui pemberian layanan-layanan dan bimbingan yang menjadi dasar utama bimbingan dan konseling oleh konselor sekolah [2].
Konselor memiliki tanggung jawab profesional untuk menunjukkan perubahan yang lebih baik pada siswa [3]. Evaluasi memberikan gambaran mengenai keberhasilan intervensi yang guru lakukan, perlu dipertahankan atau diperbaiki, yang pada akhirnya membantu konselor sekolah untuk melaporkan hasil kerja mereka kepada stakeholder (Orang tua, dewan sekolah, dll). Keterbukaan informasi kepada stakeholder, memperbesar kepuasan [4], manfaat [2], efisiensi dan efektifitas program atau layanan yang diberikan kepada siswa dan peningkatan kesadaran dan pemahaman akan peran BK di sekolah [3], dengan mengevaluasi layanan yang konselor sekolah lakukan mereka mampu mempertanggung jawabkan, bahwa apa yang mereka 
kerjakan terbukti efektif pada siswa mereka [3]. Selain itu, peningkatan hasil positif pada siswa akibat pelaksanaan layanan yang dilakukan konselor sekolah, mampu menjadi salah satu bukti akuntabilitas kinerja konselor sekolah kepada para stakeholder bimbingan dan konseling.

Tugas pokok yang sejatinya akan meningkatkan profesionalisme guru, konselor perlu melaksanakan evaluasi untuk memperoleh penyelenggaraan layanan dasar yang sesuai dengan harapan siswa serta berkualitas. Hasil dari pelaksanaan evaluasi program bimbingan dan konseling melalui kegiatan layanan dasar dijadikan konselor sebagai pengembangan program bimbingan dan konseling di sekolah. Hal ini merupakan bagian dari standarisasi kinerja konselor sekolah yang salah satunya yaitu menyusun program bimbingan dan konseling yang sesuai dengan kebutuhan siswa

Pelaksanaan evaluasi yang dilakukan oleh konselor sekolah masih perlu perhatian yang serius. Penelitian yang dilakukan Rachmalia [5] mengenai pelaksanaan tugas pokok konselor sekolah, menunjukkan bahwa untuk aspek evaluasi bimbingan konseling masih banyak konselor sekolah yang belum melakukannya. Konselor sekolah yang selalu melakukan evaluasi terhadap layanan mereka untuk mengetahui seberapa besar kesuksesannya hanya $18.75 \%$.

Penelitian lain yang mengungkap tingkat pelaksanaan evaluasi konselor sekolah terhadap layanan yang diberikannya di SMAN wilayah Jakarta Timur dilakukan oleh Yusuf [6] didapatkan data bahwa sebesar 70,82\% konselor sekolah melaksanakan evaluasi perencanaan, $49,62 \%$ melaksanakan evaluasi proses, dan $69,14 \%$ melaksanakan evaluasi hasil. Artinya evaluasi yang lebih sering dilaksanakan adalah evaluasi perencanaan. Kemudian evaluasi hasil, dan yang paling rendah tingkat intensitas pelaksanaannya adalah evaluasi proses.

Menurut Yusuf [6], pelaksanaan evaluasi proses menjadi yang terendah dikarenakan dalam pelaksaaan program bimbingan dan konseling guru menghadapi berbagai kendala seperti tidak memiliki banyak waktu untuk mendiagnosis kelebihan dan kekurangan program bimbingan dan konseling yang dilaksanakan, tidak memiliki cukup data atau informasi terkait dengan kelebihan dan kekurangan program bimbingan dan konseling yang dilaksanakan, kurangnya kompetensi konselor sekolah untuk menentukan kriteria evaluasi dan kurangnya daya guna konselor sekolah untuk melaksanakan secara sungguh-sungguh suatu evaluasi proses program BK secara berkesinambungan. Hal ini senada dengan pendapat Isaacs [4], bahwa para konselor sekolah yang memiliki resistensi terhadap perubahan cara kerja dikarenakan kurangnya keterampilan, kurangnya kepercayaan diri akan kemampuan, dan kurangnya motivasi dalam belajar.

Hadirnya bantuan untuk memudahkan pelaksanaan evaluasi yang harus dilakukan konselor sekolah dan mengatasi hambatan menjadi hal yang mutlak diperlukan, sebagai penyeimbang akan tuntutan tanggung jawab konselor sekolah. Teknologi menjadi salah satu alternatif yang terlihat dapat menjanjikan kemudahan-kemudahan yang dibutuhkan. Pengunaan teknologi dalam pelaksanaan layanan bimbingan dan konseling dapat membantu konselor sekolah menjalankan setiap tugasnya dengan lebih mudah [7]. Salah satunya dapat diterapkan terkait pelaksanaan evaluasi proses layanan bimbingan dan konseling.

Layanan dasar dapat diartikan sebagai proses pemberian bantuan kepada seluruh peserta didik melalui kegiatan yang memberikan pengalaman terstruktur secara klasikal atau kelompok [8], dan dilakukan untuk seluruh peserta didik dan dalam jangka waktu yang panjang (Rambu-Rambu Penyelenggaraan BK di Pendidikan Formal, 2007). Berdasarkan konsep layanan dasar yang telah dikemukakan, pelaksanaan layanan dasar di Indonesia didasarkan atas SKKPD (Standar Kemandirian Peserta Didik) yang berbeda sesuai dengan level perkembangan peserta didik. SKKPD inilah yang nantinya akan menjadi acuan para guru BK dalam menyusun rencana pelaksanaan layanan dasar bagi seluruh siswa di Sekolah. Kesesuaian standar kemandirian peserta didik ini menjadi salah satu syarat agar layanan dasar dapat dikatakan berjalan dengan benar dan baik.

Implementasi layanan dasar biasanya dilakukan dalam aktivitas kelas seperti pengajaran yang dilakukan konselor (mengajar berkelompok dengan pihak-pihak yang terkait dengan materi) dan kegiatan sekolah lainnya (career day, educational day, vocational day), dan lain-lain. Berdasarkan PERMEN 111 tahun 2014 [9], kegiatan-kegiatan yang dapat dilakukan oleh Konselor atau Guru Bimbingan dan Konseling dalam komponen layanan dasar antara lain; asesmen kebutuhan, bimbingan klasikal, bimbingan kelompok, pengelolaan media informasi, dan layanan bimbingan dan konseling lainnya. Fokus pengembangan kegiatan yang dilakukan pada implementasi layanan dasar, diarahkan pada perkembangan aspek-aspek pribadi, sosial, belajar dan karir siswa. Semua ini berkaitan erat dengan upaya membantu siswa untuk mencapai tugas-tugas perkembangan dan tercapainya kemandirian siswa.

Implementasi layanan dasar, memfasilitasi semua peserta didik untuk mendapatkan layanan bimbingan dan konseling secara terencana, teratur dan sistematis serta sesuai dengan kebutuhan. Dukungan dari staff sekolah, guru mata pelajaran lain, kepala sekolah, orang tua dan semua pihak yang terkait sangat dibutuhkan untuk mencapai kesuksesan implementasi layanan.

Evaluasi sebagai proses pengumpulan dan analisis data atau informasi yang terencana dan sistematis, yang digunakan untuk memperlihatkan efektifitas, hasil, dan dampak dari sebuah program, membuktikan akuntabilitas, dan mengidentifikasi hal-hal yang perlu diperbaiki dan dikembangkan, dan mempengaruhi pembuatan keputusan di area lokal (Dimmit et al., dalam [10]. Serupa dengan Loesch dalam Dimmit [10] yang menyatakan bahwa evaluasi program konseling membantu para praktisi BK untuk memaksimalkan efektifitas dan efisiensi dari layanan yang mereka berikan dengan memeriksa dengan hati-hati dan sistematis setiap komponen program, metodenya, dan hasilnya, yang pada akhirnya akan membantu guru BK untuk menunjukkan akuntabilitas pekerjaan mereka. Untuk mengetahui seberapa baik intervensi atau program yang 
sedang dijalankan, melihat apa saja yang berjalan baik, apa yang perlu ditingkatkan, dan apa saja yang perlu dilakukan dengan cara berbeda maka dilakukanlah evaluasi proses layanan dasar.

Evaluasi proses merupakan kegiatan berkala yang dilakukan dengan tujuan untuk mendapatkan informasi terkait intervensi yang sedang dilakukan, sebagai dasar memperbaiki intervensi tersebut, menilai melihat apa saja yang berjalan baik, apa yang perlu ditingkatkan, dan apa saja yang perlu dilakukan dengan cara berbeda sesuai dengan keadaan yang terjadi. Guna mencapai tujuan tersebut terdapat empat komponen dalam evaluasi proses layanan dasar yaitu: (1) Materi yang ditetapkan dalam layanan dasar, (2) Metode yang digunakan (3) Media yang digunakan dan (4) Manfaat dari kegiatan bimbingan.

Adapun langkah-langkah dalam melakukan evaluasi proses layanan dasar adalah sebagai berikut: (1) Menyusun rencana evaluasi, (2) Mengumpulkan data evaluasi, (3) Melakukan analisis data evaluasi, (4) Mengambil keputusan dan rekomendasi, (5) Penyusunan laporan evaluasi dan menyampaikannya.

Pada perancangan sebuah alat yang akan digunakan untuk membantu pengolahan data evaluasi pendidikan dengan teknik pengujian validitas item hasil belajar memanfaat kan sebuah sistem informasi pengolah data. Pemanfaatan sistem informasi erat kaitannya dengan pemanfaatan teknologi informasi. Website atau disingkat web, dapat diartikan sekumpulan halaman yang terdiri atas beberapa laman yang berisi informasi dalam bentuk data digital, baik berupa teks, gambar, video, audio dan animasi lainnya yang disediakan melalui jalur koneksi internet [11]. Menurut Nielsen [12], untuk mengetahui daya guna suatu sistem dilihat dari 5 komponen yaitu: (1) Mudah untuk dipelajari, (2) Efisien untuk digunakan, (3) Mudah untuk diingat, (4) Tingkat frekuensi kesalahan, (5) Tingkat kepuasaan pemakai.

\section{METODE}

APPRODA merupakan sistem yang dikembangkan APPRODA merupakan sistem ayng dikembangkan untuk membantu guru BK dalam mengevaluasi proses kegiatan layanan dasar. APPRODA dikembangkan dengan metodologi Research and Developmet hingga tahap ke-6. Pada tahap ke-1 peneliti melakukan riset untuk mencari potensi masalah yang terjadi terkait evaluasi proses layanan dasar BK dengan melihat dari studi literatur maupun penelitian yang relevan. Pada tahap ke-2 peneliti melakukan pengumpulan data yang mendukung dalam pengembangan produk dengan melakukan penyebaran studi pendahuluan atau studi kebutuhan pengguna terhadap sistem. Pada tahap ke-3 peneliti mulai mengembangkan sistem berdasarkan hasil analisis kebutuhan yang telah dilakukan. Pada tahap ke-4 peneliti melakukan validasi produk yang telah berhasil dikembangkan dengan melibatkan ahli materi dan ahli media. Pada tahap ke-5 peneliti kembali melakukan pembaharuan atau revisi produk berdasarkan masukkan dan penilaian dari ahli dan pada tahap ke-6 peneliti melakukan uji coba produk dengan melibatkan pengguna. APPRODA berhasil dikembangkan berupa sistem berbasis website dengan jaringan aktif (online). APPRODA memberikan fasilitas pelaksanaan evaluasi proses layanan dasar dengan tiga hak otoritas yaitu administrator, tenaga pendidik (guru BK) dan peserta didik.

\section{HASIL DAN PEMBAHASAN}

\section{A. HASIL}

Berdasarkan hasil studi pendahuluan yang dilakukan di SMAN 43 Jakarta pada bulan Februari dengan cara berkomunikasi langsung dengan salah satu koordinator guru BK, yang juga teman baik dari komunitas MGBK. Dari hasil komunikasi itu memberikan gambaran bahwa sekolah yang bersangkutan belum sepenuhnya melakukan kegiatan evaluasi kegiatan BK khususnya evaluasi proses layanan dasar yang berbasis websitedikarenakan keterbatasan kemampuan serta daya dukung dari personil guru BK yang lain.

Pengumpulan data studi pendahuluan dilakukan dengan dua cara pertama untuk studi pendahuluan yang diperuntukan bagi tenaga pendidik angket disebarkan menggunakan google form dengan melibatkan 14 guru BK se-Jakarta Selatan dan untuk penyebaran angket studi pendahuluan bagi peserta didik dilakukan di dua sekolah berbeda dengan melibatkan 124 peserta didik. Berdasarkan hasil studi pendahuluan, pengklasifikasian studi kebutuhan dibedakan berdasarkan dua kebutuhan yaitu kebutuhan pengguna (user) dan kebutuhan aplikasi (system).

Berdasarkan hasil analisis assesment kebutuhan pengguna diketahui bahwa: (1) Evaluasi proses layanan dasar BK dilakukan tenaga pendidik disekolah, (2) Penggunaan angket pada evaluasi proses dipilih untuk mengetahui atau mengevaluasi proses pemberian layanan dasar disekolah, (3) Penggunaan aplikasi pembantu dalam melaksanakan evaluasi proses masih sangat minim. Beberapa dari aplikasi yang digunakan tenaga pendidik seperti AKPD, ITP dan DCM. Namun tenaga pendidik lebih sering menggunakan penyebaran angket secara manual dalam mengumpulkan data evaluasi proses, (4) Tenaga pendidik membutuhkan alat/media yang dapat membantu dan mempermudah pelaksanaan evaluasi proses yang dapat merencanakan evaluasi, melibatkan peserta didik dalam evaluasi dan melaksanakan analisis berdasarkan informasi yang didapatkan (5) Tenaga Pendidik membutuhkan alat/media yang dapat menjadi inventori atau media penyimpanan hasil evaluasi yang dilakukan, aplikasi diharapkan dapat mepermudah tenaga pendidik dalam pelaksanaan evaluasi proses dengan memberikan hasil analisis yang valid dan dapat menghemat waktu pelaksanaan evaluasi proses di sekolah.

Berdasarkan hasil analisis assesment kebutuhan sistem (aplikasi) diketahui bahwa: (1) Sistem harus dapat menampilkan pendapat peserta didik tentang evaluasi proses yang dilakukan dan dapat memberikan hasil analisis secara otomatis, (2) Sistem dibuat dalam bentuk website online supaya dapat digunakan disemua perangkat komputer dan smartphone/HP dengan menggunakan browser yang tersedia disemua sistem operasi, (3) Sistem harus dibuat menarik 
dengan menggunakan beberapa paduan warna, gambar, animasi dan penggunaan font standar, (4) Sistem harus dapat memberikan fasilitas pendaftaran kepada tenaga pendidik dan peserta didik secara mandiri, (5) Sistem menggunakan angket untuk pengumpulan informasi dalam bentuk pilihan ganda dengan menggunakan opsi ya, tidak atau menggunakan skala guttman, (6) Sistem harus dilengkapi dengan buku panduan dan dibuat sederhana untuk menghindari error.

Hasil studi kebutuhan sistem dan pengguna menjadi dasar dalam perancangan Aplikasi Evaluasi Proses Layanan Dasar (APPRODA) yang membantuk guru BK dalam melaksanakan proses evaluasi proses layanan dasar di sekolah. Melihat dari hasil kebutuhan pengguna dan kebutuhan sistem maka untuk menggambarkan produk yang akan dikembangkan, rancangan digambarkan dengan menggunakan diagram alir / flowchart. Adapun rancangan APPRODA digambarkan sebagai berikut:
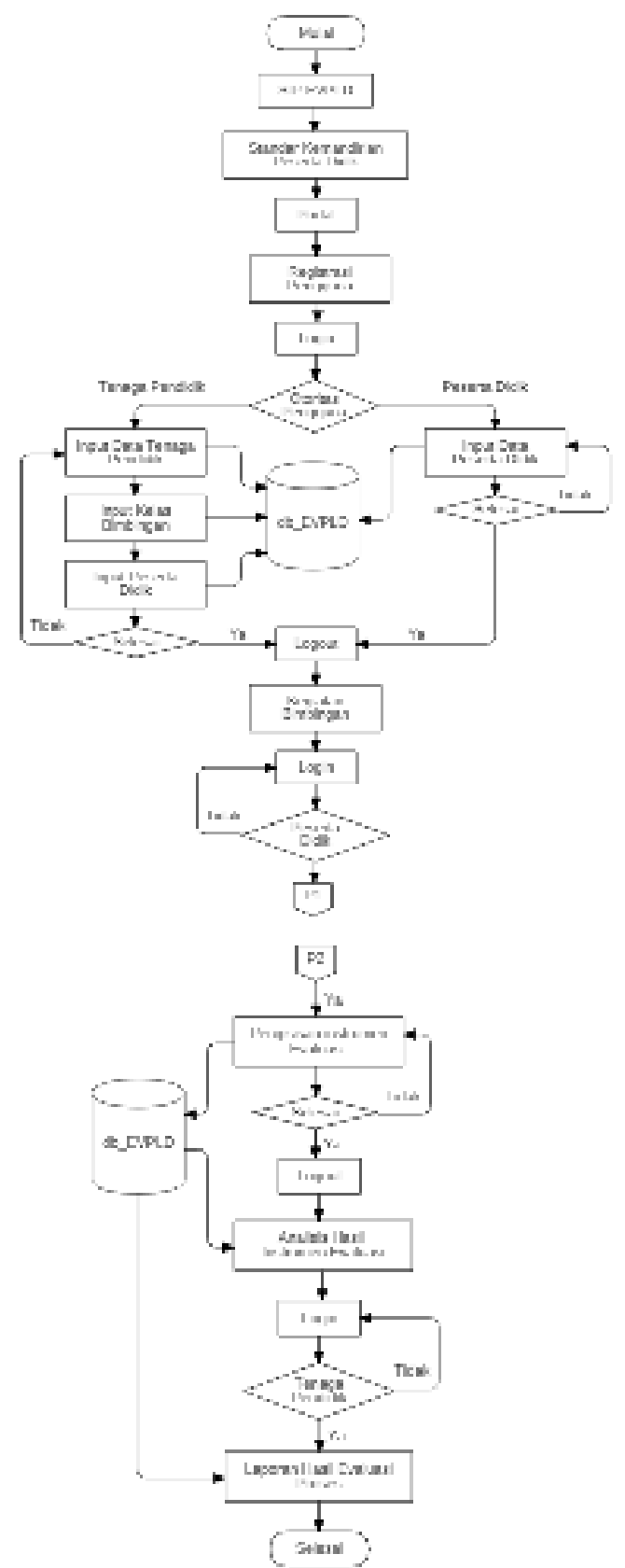

Gambar 1. Flowchart perancangan APPRODA

APPRODA berhasil dikembangkan berupa sistem berbasis website dengan jaringan aktif (online) dapat diakses pada halaman url approda.000webhostapp.com, APPRODA memberikan fasilitas pelaksanaan evaluasi proses layanan dasar dengan tiga hak otoritas yaitu administrator, tenaga pendidik (guru BK) dan peserta didik. 


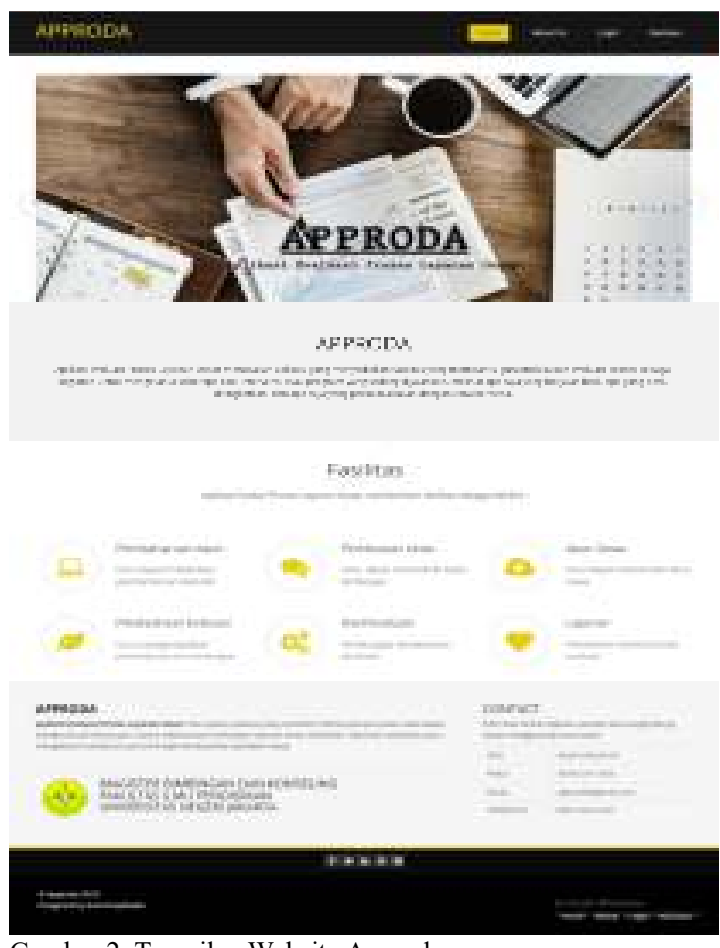

Gambar 2. Tampilan Website Approda

Untuk mengetahui kelayakan dari APPRODA dilakukan validasi oleh ahli materi dan media dengan hasil sebagai berikut: Analisis ahli materi dilakukan di gedung RA. Kartini lantai 7, Ruang diskusi pada tanggal 28 januari 2019 dengan pengisian angket oleh Sudarno Dwi, M.Pd selaku Dosen Evaluasi Bimbingan dan Konseling Universitas Muhammadiyah Prof. Hamka (Uhamka). Hasil pengujian ahli materi dilakukan dengan perhitungan angket Rating Scale pada setiap aspek pada alpha test, Angka presentase yang diperoleh pada uji ahli materi pada APPRODA adalah $92,94 \%$ yang berada pada kategori sangat layak sehingga dapat dikatakan bahwa APPRODA telah memiliki kesesuaian dengan materi evaluasi proses layanan dasar.

Pengujian ahli media (alpha test) website APPRODA dilakukan di Kampus Universitas Negeri Jakarta tepatnya di gedung Sertifikasi guru pada tanggal 04 Februari 2019 dengan pengisian angket oleh bapak Dr. Khaerudin, M.Pd. Hasil pengujian alpha test dilakukan dengan perhitungan angket Rating Scale pada setiap aspek pada alpha test. Angka presentase yang diperoleh pada uji ahli media pada APPRODA adalah 71,42\% yang berada pada kategori layak sehingga dapat dikatakan bahwa APPRODA telah memiliki kesesuaian dengan media yang baik. Berdasarkan hasil uji ahli materi dan media oleh penguji didapat beberapa revisi yang harus dilakukan pada sistem yaitu sesuai dengan masukkan ahli materi berupa penambahan cetak laporan berupa PDF dan penambahan import data siswa menggunakan excel sedangkan perbaikan sistem sesuai dengan masukkan ahli media berupa penambahan informasi penggunaan, syarat dan ketentuan pada setiap halaman pengguna.
Pengujian efektivitas dilakukan dengan melibatkan Guru BK berjumlah 13 Guru dilakukan di SMK Muhammadiyah 5 Jakarta pada tanggal 8 Februari 2019. Hasil penilaian dilakukan dengan perhitungan angket Rating. Angka presentase yang diperoleh pada pengujian efektivitas oleh tenaga pendidik pada APPRODA adalah 97,25\% yang berada pada kategori sangat baik. Dengan demikian APPRODA dapat berfungsi dengan sangat baik bagi tenaga pendidik dalam pelaksanaan evaluasi proses layanan dasar.

\section{B. PEMBAHASAN}

Berdasarkan hasil penelitian dan pembahasan, perancangan Aplikasi Evaluasi Proses Layanan Dasar (APPRODA) diharapkan dapat dikembangkan dalam menyelesaikan kesulitan dan menjadi solusi dalam pelaksanaan evalusi proses layanan dasar.

Adapun tujuan dari perancangan APPRODA: (1) APPRODA dapat memberikan informasi tentang prosedur evaluasi proses pada layanan dasar Bimbingan dan Konseling, (2) APPRODA dapat membantu guru dalam penginputan data, manajemen data, analisis data hasil evaluasi proses dan pembuatan laporan evaluasi proses, sehingga pelaksanaan evaluasi proses dapat berjalan dengan efektif, (3) APPRODA dapat mengatasi kesulitan dalam pengimputan data, manajemen data, analisis data dan pembuatan laporan, (4) APPRODA dapat menjadi alat bantu evaluasi proses yang layak untuk membantu koselor sekolah dalam mempermudah prosedur evalusi proses layanan dasar Bimbingan dan Konsesling.

APPRODA merupakan sistem yang dikembangkan untuk membantu guru BK dalam mengevaluasi proses kegiatan layanan dasar. APPRODA dikembangkan dengan metodologi Research and Developmet hingga tahap ke-6. Pada tahap ke-1 peneliti melakukan riset untuk mencari potensi masalah yang terjadi terkait evaluasi proses layanan dasar BK dengan melihat dari studi literatur maupun penelitian yang relevan. Pada tahap ke-2 peneliti melakukan pengumpulan data yang mendukung dalam pengembangan produk dengan melakukan penyebaran studi pendahuluan atau studi kebutuhan pengguna terhadap sistem. Pada tahap ke-3 peneliti mulai mengembangkan sistem berdasarkan hasil analisis kebutuhan yang telah dilakukan. Pada tahap ke-4 peneliti melakukan validasi produk yang telah berhasil dikembangkan dengan melibatkan ahli materi dan ahli media. Pada tahap ke-5 peneliti kemabali melakukan pembaharuan atau revisi produk berdasarkan masukkan dan penilaian dari ahli dan pada tahap ke-6 peneliti melakukan uji coba produk dengan melibatkan pengguna. APPRODA berhasil dikembangkan berupa sistem berbasis website dengan jaringan aktif (online). APPRODA memberikan fasilitas pelaksanaan evaluasi proses layanan dasar dengan tiga hak otoritas yaitu administrator, tenaga pendidik (guru BK) dan peserta didik.

Berdasarkan hasil validasi ahli media, APPRODA masuk dalam kategori sangat layak dengan didapat nilai presentase sebesar 92,94\% sehingga APPRODA telah memiliki kesesuaian pada materi evaluasi proses layanan dasar dan dapat diuji coba pada pengguna, meskipun 
APPRODA dikategorikan sangat layak oleh ahli materi namun ada beberapa saran atau masukkan yang belum dapat diakomodir oleh APPRODA yaitu penyajian laporan evaluasi dapat diunduh dalam format word atau excel. Berdasarkan hasil ahli materi, APPRODA masuk dalam kategori layak dengan didapat nilai presentase sebesar $71,42 \%$ sehingga APPRODA telah memiliki kesesuaian dengan media yang baik dan dapat diuji coba pada pengguna, meskipun APPRODA dikategorikan layak oleh ahli media namun ada beberapa saran atau masukkan yang belum dapat diakomodir oleh APPRODA yaitu pengujian kembali untuk mengetahui tingkat keamanan sistem dengan melibatkan ahli IT atau tenaga teknis.

APPRODA mengalami revisi sebelum diuji coba kepada pengguna, revisi yang dilakukan yaitu: (1) Penambahan fitur import data peserta didik dengan format excel, (2) Penambahan cetak / download PDF dan evaluasi kuatilatif oleh tenaga pendidik (guru BK), (3) Penambahan informasi penggunaan (syarat dan ketentuan) pada halaman tenaga pendidik dan peserta didik. Setelah revisi selesai maka APPRODA dapat diuji coba pada pengguna. Dalam uji coba, APPRODA melibatkan tenaga pendidik (guru BK) dengan hasil presentase sebesar 97,25\% sehingga APPRODA dikategorikan sangat membantu dalam evaluasi proses layanan dasar.

\section{KESIMPULAN}

Berdasarkan hasil penelitian mengenai pengembangan Aplikasi evaluasi proses layanan dasar bimbingan dan konseling di SMA diperoleh kesimpulan sebagai berikut:

1. Penelitian yang sudah dilakukan menghasilkan produk, yaitu Aplikasi Evaluaasi Proses Layanan Dasar Bimbingan dan Konseling di SMA. Sistem Aplikasi evaluasi proses layanan dasar ini merupakan aplikasi berbentuk website yang memberikan fasilitas kepada pengguna dalam mempermudah pelaksanaan evalauasi layanan dasar bimbingan dan konseling di sekolah yang hasilnya bisa di akses secara otomatis.

2. Produk akhir dari aplikasi Evaluasi Proses Layanan Dasar bimbingan dan konseling telah di evaluasi oleh ahli Media, ahli Materi dan pengguna. Ahli Media yang dilibatkan adalah Dr. Khaerudin, M.Pd. Ahli Materi dilibatkan Dwi Sunarno, M.Pd. (Dosen evaluasi BK di Universitas Prof. Dr. Hamka). Pengguna yang dilibatkan adalah Guru Bimbingan dan Konseling se-Jakarta Selatan.

3. Hasil evaluasi ahli media adalah aplikasi system informasi peminatan dianggap sangat layak, isi konten dianggap menarik, relevan, bermanfaat, gaya bahasa mudah dipahami dan kontak pantas dengan guru BK. Hasil struktur dan navigasi mudah, konsisten, ketersediaan struktur dan navigasi untuk memberikan feedback terhadp website. Desain Visual sangat menarik, sangat logis ukuran file (grafis) dan daya dukung grafis terhadap konten, struktur dan navigasi sangat bagus. Bagian fungsional website terbatas pada assessment, tingkat fungsional konten dan modul website sangat bagus. Subjek matter sesuai dengan tujuan, urutan perintah dan terdapat petunjuk penggunaan. Aplikasi evaluasi proses layanan dasar BK di SMA ini mudah digunakan dan dipelajari serta keamanannya bagus melalui NISN dan kerahasiaan cukup terjamin dalam penggunaan

4. Hasil evaluasi ahli Materi yaitu System Aplikasi evaluasi proses layanan dasar BK di SMA (Approda) sudah sesuai dengan teori. Hasil evaluasi kegunaan bahwa produk sesuai dengan guru BK dan mudah dipelajari.

5. Hasil evaluasi kegunaan yang dilakukan oleh guru BK menunjukan sistem aplikasi evaluasi proses layanan dasar (Approda) sangat layak untuk digunakan oleh guru BK, mudah dijalankan serta dapat menampilkan secara otomatis hasil evaluasi proses layanan dasar yang sudah dilakukn oleh guru BK.

Implikasi yang didapatkan dalam penelitian ini adalah Sistem Aplikasi Evaluasi Proses Layanan Dasar Bimbingan dan Konseling di SMA layak digunakan oleh Guru Bimbingan dan Konseling dalam skala nasional khususnya di indonesia untuk mempermudah proses kegiatan bimbingan dan konseling, khususnya pada kegiatan evaluasi layanan dasar bimbingan dan konseling.

Berdasarkan pembahasan yang telah dipaparkan oleh peneliti diharapkan Aplikasi Evaluasi Proses Layanan Dasar BK (Approda) dapat dikembangkan kembali oleh para peneliti selanjutnya, serta tentunya sesuai dengan kaidahkaidah evaluasi yang sudah ada baik dari segi teori maupun rujukaan dari studi pendahuluan yang sudah dilakukan.

\section{DAFTAR PUSTAKA}

[1] Kesici, S. (2007). Middle School Students' Guidance and Counseling Needs. Kuram ve Uygulamada Egitim Bilimleri, 7(3), 1325.

[2] Gysbers, N. C, \& Henderson, P. (2006). Developing and Managing. Your School Guidance and Counseling Program. American counseling Association: Alexandria.

[3] Dimmitt, C. (2009). Why Evaluation Matters: Determining Effective School Counseling Practices. Professional School Counseling, 12(6), 395-399.

[4] Isaacs, M. L. (2003). Data-Driven Decision Making: The Engine of Accountability. Professional School Counseling, 6(4), 228-295.

[5] Rachmalia, N. (2006). Evaluasi Guru Bimbingan dan Konseling. Fakultas Ilmu Pendidikan, Bimbingan Konseling Universitas Negeri Jakarta.

[6] Yusuf, M. (2011). Tingkat Pelaksanaan evaluasi program Bimbingan dan konseling \& Faktor penghambat evaluasi program BK (Survey pada guru Bimbingan konseling di SMAN Wilayah Jakarta Timur. Skripsi. Jurusan Bimbingan Konseling, Fakultasi Ilmu Pendidikan UNJ.

[7] Carey, J., \& Dimmitt, C. (2004). The Web and School Counseling. Computers in the Schools, 21(3-4), 69-79.

[8] Furqon \& Badrujaman, A. (2014). Model Evaluasi Layanan Dasar Berorientasi Akutabilitas. Jakarta: PT. Indeks.

[9] Peraturan Menteri Pendidikan dan Kebudayaan Republik Indonesia Nomor 111 Tahun 2014 tentang Bimbingan Dan Konseling pada Pendidikan Dasar dan Pendidikan Menengah. (2014). Indonesia. Kementerian Pendidikan dan Kebudayaan.

[10] Dimmit, C. (2010). Evaluation in School Counseling: Current Practices and Future Possibilities. Counseling Outcome Research and Evaluation, 1, 44-56.

[11] Abdulloh, R. (2016). Easy \& Simple Web Programming, Jakarta : PT Elex Media Komputindo.

[12] Neilsen, J. (2003). Usability 101 : Introduction to Usability. Diakses Januari 2019 dari http://useit.com/alretbox/20030825.html. 